Ann. Zootech., I979, 28 (4), 373-379.

\author{
I.N.R.A. \\ BIBLIOTHEQUE UO 3593? \\ DOMAINE DE CROUELLi \\ 63039 \\ Clermont-FD CeDexz
}

\title{
In vitro prediction of whole ration digestibility
}

\author{
Sylvie GIGER $\left(^{*}\right)$, M. IIIA $\left(^{* *}\right)$, D. SAUVANT $\left(^{*}\right)$ et P. MORAND-FEHR $\left(^{*}\right.$ \\ (*) Laboratoive de Recherches de la Chaive de Zootechnie I.N.R.A. \\ Institut National Agronomique, Paris-Grignon, \\ I6, rue Claude-Bernard, 7523I Paris Cedex o5 \\ (**) Station d'Amélioration des Plantes Fourragères I.N.R.A., \\ 86600 Lusignan (France)
}

\section{Summary}

In vitro digestibility measures allow to predict the in vivo digestibility of roughage organic matter with a better accuracy than the proximate chemical analysis. In the present study a comparison was made using mixed diets fed to lactating dairy goats at various levels of intake and proportions of concentrates. Moreover, two kinds of concentrate feeds varying by their proportion of cell-wall constituents were studied. The in vitro digestibility technique applied to feedstuffs taken separately or combined in the same proportions as those of the ingested diet allowed to predict the in vivo digestibility of the whole diet with a higher accuracy than that of the proximate chemical analysis.

\section{Introduction}

Digestibility of the organic matter is the most important factor of the energy value of feedstuffs. However, the most fitted criterion liable to predict digestibility and consequently the energy value of feedstuffs is the crude fibre content. Since a long time, experimental data have shown the limitations of this predictor (NORMAN, I935) and research has therefore been undertaken resulting in the development of several methods such as the two stage in vitro digestibility method suggested by TILLEY and TERRY (I963).

Experimental results showed that this technique, applied in a well defined manner (BAUMGARDT and $\mathrm{OH}$, I964), might predict forage digestibility more accurately than chemical methods (OH, BAUMGARDT and SCHOLL, I966; DEINUM and VAN SOEST, I969; VAN DER KOELEN and VAN Es, I973; AERTS et al., I977).

But the two stage in vitro technique has not been applied to mixed rations very often. A few experimental data obtained with such rations seem to show that the in vivo digestibility can be well estimated by this in vitro method (KumENo, 
Dehority and Johnson, I967; KLETT, I967; NiK-KhAH and Tribe, I977). Only mixed rations provide enough energy to lactating females according to their high needs. The present study was carried out in order to determine the ability of the in vitro rumen fermentation method to predict the in vivo digestibility of mixed rations. Diets with widely varying hay to concentrate ratios were fed to goats with various levels of intake and milk yields.

\section{Material and methods}

\section{A. - In vivo trial}

The in vivo trial was performed on two groups of three goats housed in the metabolism crates described by GIGER and HERVIEU (I980). It lasted nine weeks and was divided into three periods of three weeks each. For every period, digestibility measures were undertaken at the second and third week during five consecutive days. A constant and restricted level of lucerne hay was fed (I I50 g D. M. / d) and the concentrates were offered according to milk yield ( $\mathrm{r} 7 \mathrm{O}$ to I $250 \mathrm{~g}$ D. M./d). The quantities of concentrates fed are given in table I.

TABLEAU I

Quantities of concentrates fed to the goats ( $g$ D.M./d)

Quantités d'aliments concentrés distribués aux chèvres ( $g$ M.S. $/ j$ )

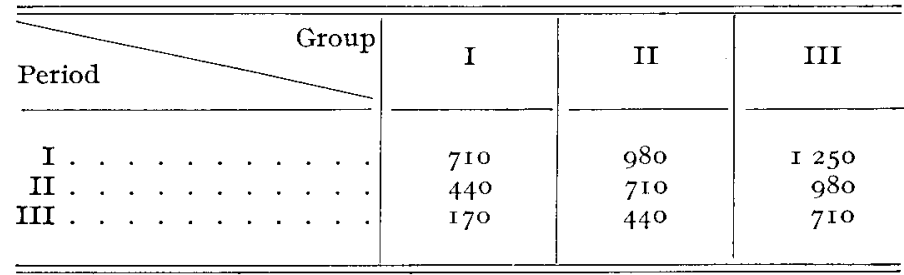

TABLEAU 2

Composition of the experimental concentrates

Composition des aliments concentrés expérimentaux

Riche en énergie

High in energy: $H$

Pulpe de betterave (Sugar beet pulp) Maîs grain (Maize) . ........ . . Graines de lupin (Lupine) . . . . Tourteau de soja (Soybeanmeal 44) $44,0 \%$ I $7,8 \%$ $6,5 \%$ $2,7 \%$

Mélasse (Molasses) . . . . . . . 7,0\% CMV (Vitamin-mineral mixture) . . 3,0\%

\section{Pauvre en énergie}

Low in energy: I
Son de blé (Wheat bran) . . . . 62,0\% 个. de coprah (Coconut maal) . . . $13,2 \%$ $\boldsymbol{T}$. de soja (Soybeanmeal 44) . . . $10,3 \%$ Luzerne déshydratée (Dehydrated lucerne meal) . . . . . . . . . . 4,5\% Mélasse (Molasses). . . . . . . $\quad 7,0 \%$ CIMV (Vitamin-mineral mixture) . $\quad 3,0 \%$ 
The two groups of animals were given two different concentrates. The concentrates were formulated by linear programming. The results of the proximate chemical analysis were the same for both, but the net energy value for lactation expressed in milk feed unit (I.N.R.A., I978) was maximized for the first concentrate (concentrate $\mathrm{H}:$ high), minimized for the second one (concentrate $\mathrm{L}_{\text {: }}$ low). The composition of the concentrates is given in table 2 .

The cell-wall composition of these concentrates determined according to the VAN SOEST method (GOERING and VAN SOEST, I970) modified by Sylvie GIGER et al. (I979a) for semi-automatic use of concentrates was very different, whereas the crude fibre content (AFNOR, I977) was almost the same (see table 3).

\section{TABLEAU 3}

Fibre composition of the jeedstuffs offered

Composition membranaire des différents aliments

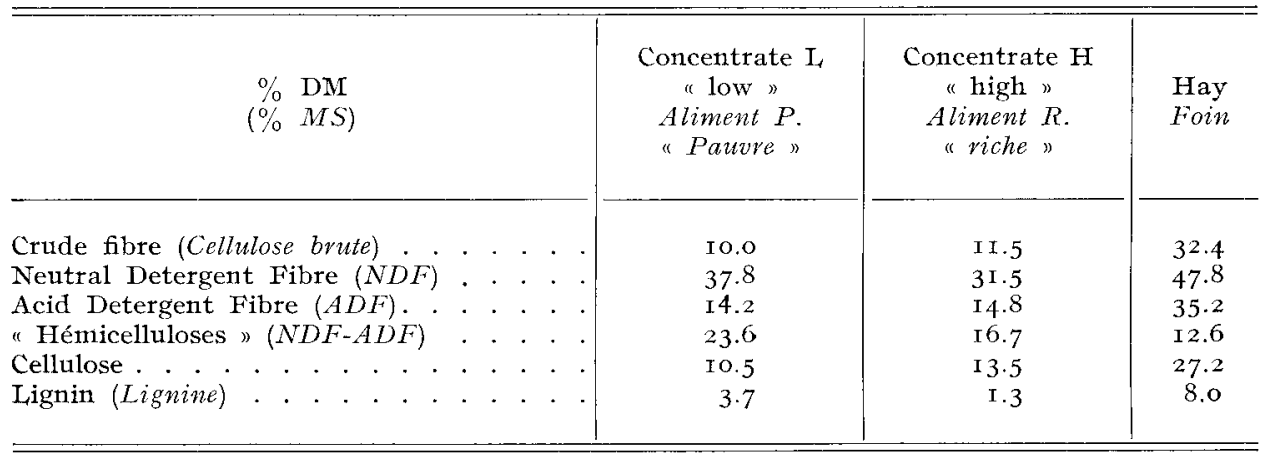

\section{B. - In vitro trial}

The in vitro digestibility was estimated by means of the technique of TILLEY and TERRY (I963) modified by ALEXANDER and Mc GowAN (I966). 'Two methods were used.

\section{Method I}

The in vitro digestibility of samples of the two dietary components (hay and concentrates) was measured and the estimation of the in vitro digestibility of the ration was calculated for each of the six weeks of in vivo digestibility measurements according to quantities of hay and concentrates actually eaten by the goats.

\section{Method 2}

The in vitro digestibility of the ration was evaluated as a whole: each sample was a mixture of hay and concentrates in the same proportion as in the rations fed to the animals. Such a sample was prepared for each goat and for each experimental week. 


\section{Results and Discussion}

In the present trial, the in vivo dry matter (D.M.D.) and organic matter (O.M.D.) digestibility were negatively correlated with the crude fibre content (C.F.).

$$
\begin{array}{ll}
\text { D.M.D. }=82.6-0.70 \text { C.F. } & (r=-0.64, n=36) \\
\text { O.M.D. }=84.9-0.7 \text { O C.F. } & \left(r=-0.62, n=3^{6}\right)
\end{array}
$$

Large differences due to the diets (fig. I) were observed; they might be explained by the very different cell-wall constituents in the two experimental concentrates (table 3). For one and the same crude fibre content, a difference of five points in the in vivo organic matter digestibility of the whole diet appeared between the two types of rations (fig. I).

The equations correlating the in vivo digestibility of the dry matter and the organic matter with the in vitro digestibility of the dry matter were the following with the first method.

$$
\begin{array}{ll}
\text { D.M.D. }=0.7 \mathrm{I} 5 \mathrm{IVD}_{1}+\mathrm{I} 6.6 & (r=0.93, n=36) \\
\text { O.M.D. }=0.749 \mathrm{IVD}_{1}+\mathrm{I} 6.4 & (r=0.93, n=36) \quad(\text { fig. } 2)
\end{array}
$$

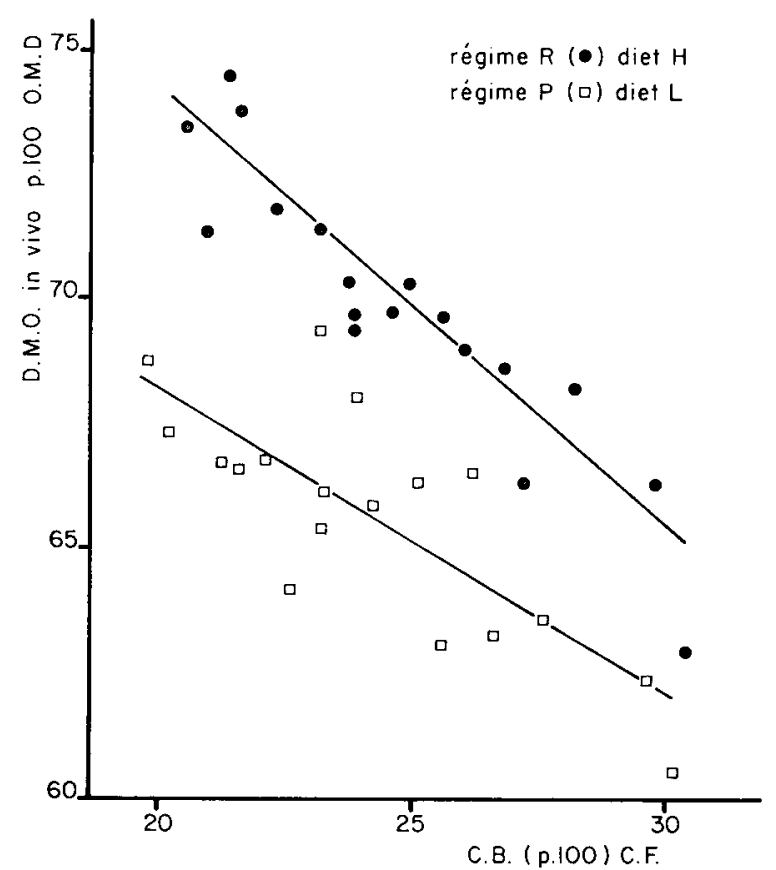

FIG. I. - Relations entre la digestibilité de la matière organique (D.M.O.) et le taux de cellulose brute de la vation totale (C.B.)

Relations between " in vivo" organic matter digestibility (O.M.D.) and the crude fiber content of the whole ration $(C . F$.

$$
y=84.9-0.70 x \quad(r=-0.62, n=36)
$$




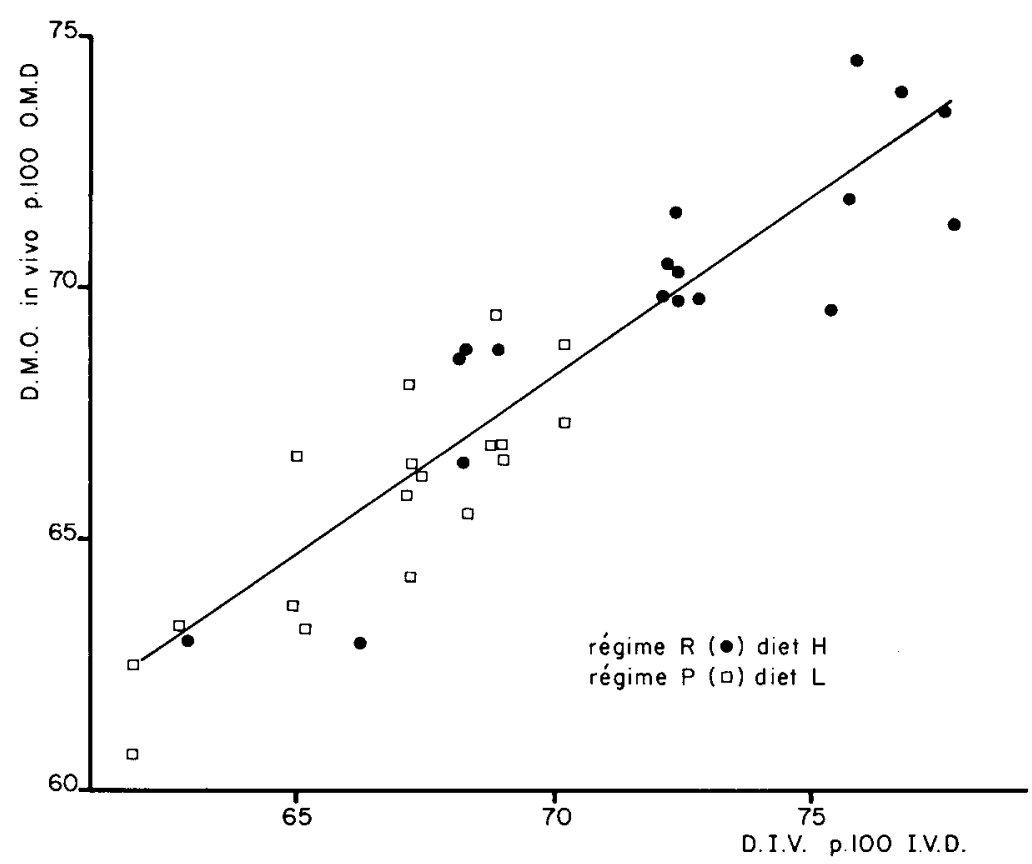

FIG. 2. - Relations entre la digestibilité de la matière organique (D.M.O.) et la digestibilité "in vitro" de la matiève sèche (D.I.V.)

Relations between: «in vivo» organic matter digestibility (O.M.D.) and «in vitro»dry matter digestibility (I.V.D.)

$$
y=0.749 x+16.4 \quad\left(r=0.93, n=3^{6}\right)
$$

and with the second method :

$$
\begin{array}{ll}
\text { D.M.D. }=0.674 \mathrm{IVD}_{2}+\mathrm{I} 8.8 & (r=0.94, n=36) \\
\text { O.M.D. }=0.688 \mathrm{IVD}_{2}+20.0 & (r=0.9 \mathrm{I}, n=36)
\end{array}
$$

The correlation coefficients between the in vivo and the in vitro digestibilities resulting from both methods were highly significant. These values were similar to those of Tilley and TERry (I963) and OH, BAumgarT and Scholi (I966), using forages only and better than those obtained by CLARK (I975) for mixtures of forages and cereals. They were more satisfactory than the crude fibre estimation and seemed not to be affected by the large differences in the cell-wall constituents.

The accurate estimation of the in vivo digestibility by means of the in vitro method could be explained by the absence of associative digestibility and a lack of effect on digestibility in connection with an increase in the level of intake as reported elsewhere (GIGER et al., I979b). In fact, the variation in the level of intake was not very large (less than two times). A greater variation might have led to another result. The absence of a digestive interaction with the variation in the proportion of concentrates in the ration ( 10 to 50 p. IOO), might perhaps be explained by their low starch content (Io to I 5 p. IOo dry matter) (KANE, JACOBson and DAmEwoon, I959) and by the restricted level of hay given. 
The slightly lower accuracy of the second method for predicting the digestibility in vivo may due to a problem arising from sampling of mixed rations.

The values recorded with the two methods were highly correlated $(r=0.92$, $n=36$ ), but the data obtained with the "whole ration" method were generally higher than those with the "separate components" method, particularly in the case of the most digestible rations. These differences might be due to the reduction of the in vitro digestibility value by a possible deficiency of degradable nitrogen in the rumen liquor (ALEXANDER and Mc GowAN, Ig66), or other growth factors which might be supplied by lucerne hay with the "reconstituted diets".

\section{Conclusion}

The in vitro digestibility method is of real interest for predicting the in vivo digestibility of ruminant mixed rations with a variable proportion of concentrates. It is much more accurate than the crude fibre content value, particularly with mixed rations which differ by their cell-wall composition although their crude fibre content, is the same.

Further studies would be required to check the ability of the in vitro measurement to satisfactorily predict the feeding value of rations rich in starch and tending to induce large associative digestibility effects.

\section{Accepté pour publication en juillet 1979.}

\section{Résumé}

\section{Prévision in vitro de la digestibilité de la ration complète}

La mesure de la digestibilité in vitro permet de prévoir la digestibilité in vivo de la matière organique des fourrages avec une précision supérieure à celle obtenue à partir des résultats de l'analyse chimique classique. Dans la présente étude, la comparaison est effectuée pour des rations complètes distribuées à des chèvres en lactation, correspondant à des niveaux d'ingestion, et des proportions d'aliments concentrés variables. En outre, deux types de composition pariétale des aliments concentrés ont été étudiés. La digestibilité in vitro, effectuée à partir des aliments pris séparément ou associés dans les proportions de la ration ingérée, permet de prédire avec une bien meilleure précision la digestibilité in vivo de la matière organique de l'ensemble de la ration que l'analyse chimique classique.

\section{References}

Aerts J. V., de Brabandir D. L., Cottyn B. G., Buysse F. X., 1977. Comparison of laboratory methods for predicting the organic matter digestibility of forages. Anim. Feed Sci. Technol., 2, 337-349.

AFNOR, I977. Détermination de l'indice d'insoluble dit " cellulosique ". Méthode générale N.F.V. 03.040.

Alexander R. H., Mc Gowan M., I966. The routine determination of in vitro digestibility of organic matter in forages - an investigation of the problems associated with continuous large-scale operation. J. Brit. Grassland Soc., 21, I40-147.

BAUMGARDT B. R., OH H. K., I964. Evaluation of forages in the laboratory. IV. - Within and among trial variability of the Wisconsin Artificial Rumen Procedure, J. Dairy Sci., 47, $263-266$. 
Jennifer Crark, I975. In vitro digestion fo mixtures of grain and hay. Austr. J. Exp. Agric. Anim. Husb., 15, 47I-474.

Deinum B., VAN SOEST P. J., I969. Prediction of forage digestibility from some laboratory procedures. Neth. J. Agric. Sci,, 17, II9-I27.

Sylvie Giger, Hervief J., ig8o. Conception d'une cage à bilan adaptée à la chèvte en lactation. Ann. Zootech. (sous presse).

Sylvie Giger, Sauvant D., Michelle Dorleans, Morand-Fenr P., i979a. Détermination semi-automatique des constituants membranaires des aliments concentrés par la méthode de VAN SOEST. 3oth meeting of EAAP, Harrogate 23-26 juillet 1979.

Sylvie Giger, Sauvant D., Hervieu J., Michelle Dorleans, Morand-Fehr P., i979b. Étude de l'influence des variations possibles de la valeur nutritive énergétique d'aliments concentrés de mêtme composition. Ann. Zootech. (à paraître).

GokRING H. K., VAn Soest P. J., 1970. Forage fiber analysis. USDA ARS Agr. Handbook $n^{\circ} 379$.

I.N.R.A., 1978. - Alimentation des ruminants. I.N.R.A. Publications Ed., 78000 Versailles.

Kane: E. A., Jacobson W. C., Damewood P. M., Jr, 1959. Effect of corn starch on digestibility of alfalfa hay. $J$. Dairy Sci., 42, 849-855.

KLETT, 1967 . A comparison of in vivo and in vitro techniques for the evaluation of varying roughage-concentrate rations. Nutr. Abstr. Rev., 38, I530.

KUMENo F., Dehority B. A., Johnson R. R., I967. Development of an in vitro fermentation technique for estimating the nutritive value of high energy mixed rations for ruminants. $J$. anim. Sci., 26, 867-871.

Nin-Khair A., Tribe D. E., 1977. A note on the effect of diet on the inoculum used in digestibility determination in vitro, Anim. Prod., 25, 103-106.

Norman A. G., 1935. The composition of crude fiber. $J$. Agric. Res., 25, 529-540.

OH H. K., Baumgardí B. R., Sciroli, J. M., ig66. Evaluation of forages in the laboratory. V. - Comparison of chemical analyses, solubility tests, and in vitro fermentations. $J$. Dairy Sci, 49, 850-855.

TIILEY J. M. A., TERRY R. A., I963. A two-stage technique for the in vitro digestion of forage crops. J. Brit. Grassland Soc., 18, I04-I I I.

VAN DER KOELEN C. J., VAN ES A. J. H., 1973. A comparison of some laboratory techniques for the estimation of the digestibility of the organic matter in forage samples. Neth. J. Agric. Sci., 21, 199-203. 